\title{
The influence of hypothyroidism and substitution treatment on thyroid hormone conversion ratios and rT3 concentration in patients with end-stage renal failure
}

\author{
Iwanna Dubczak', Longin Niemczyk ${ }^{2}$, Katarzyna Szamotulska ${ }^{3}$, Mariusz Jasik, Aleksandra Rymarz ${ }^{1}$, \\ Zbigniew Bartoszewicz ${ }^{5}$, Stanisław Niemczyk ${ }^{1}$
}

${ }^{1}$ Department of Internal Diseases, Nephrology, and Dialysis, Military Institute of Medicine, Warsaw, Poland ${ }^{2}$ Department of Nephrology, Dialysis, and Internal Medicine, Medical University of Warsaw, Poland

${ }^{3}$ Department of Epidemiology and Biostatistics, Institute of Mother and Child, Warsaw, Poland

${ }^{4} I^{\text {nd }}$ Department of Obstetrics and Gynaecology, Medical University of Warsaw, Poland

${ }^{5}$ Department of Internal Diseases and Endocrinology, Medical University of Warsaw, Poland

\begin{abstract}
Introduction: The increasing number of patients with end-stage renal disease (ESRD) requires seeking new opportunities to improve their quality of life, not only because of kidney disease but also due to other disturbances, such as thyroid hormone disorders.

The objective of the study was to evaluate the influence of coexisting hypothyroidism and thyroid hormone therapy in patients with ESRD on thyroid hormone conversion ratios and rT3 concentration.

Material and methods: The study involved 85 patients aged 26 to 87 years, with a mean age of $59.62 \pm 15.45$ years. Four groups of patients were examined: G1 group - 25 persons without RF and hypothyroidism, G2 - 26 patients with ESRD treated with haemodialysis (HD), G3 - 12 patients with ESRD treated with HD and newly diagnosed hypothyroidism, and G4 - 22 HD patients with hypothyroidism treated with thyroid hormones substitution.

The concentrations of TSH, T4, T3, fT4, fT3, and rT3 were measured and the fT3/fT4, T3/T4, and rT3/T4 conversion ratios and rT3/T3 ratio were calculated. Concentrations of protein, hsCRP, Hg, and blood gases were also checked; the anion gap was calculated.

Results: Patients from group G1 through G2 to G3 were older $\left(\mathrm{p}_{\text {trend }}=0.002\right)$, with lower Hb level $\left(\mathrm{p}_{\text {trend }}<0.001\right)$, with lower $\mathrm{pH}\left(\mathrm{p}_{\text {trend }}\right.$ $<0.001)$, with increased anion gap ( $\left.\mathrm{p}_{\text {trend }}<0.013\right)$ and CRP concentrations ( $\left.\mathrm{p}_{\text {trend }}<0.001\right)$, and decreased total protein level $\left(\mathrm{p}_{\text {trend }}<0.001\right)$. There were increased TSH values $\left(\mathrm{p}_{\text {trend }}<0.001\right)$ and lower T4 (ptrend $\left.=0.024\right)$, fT3 $\left(\mathrm{p}_{\text {trend }}<0.001\right), \mathrm{T} 3\left(\mathrm{p}_{\text {trend }}<0.001\right)$, and $\mathrm{rT3}\left(\mathrm{p}_{\text {tren }}\right.$ $=0.008)$ levels. rT3/T3 ratio did not change, the rT3/T4 ratio tended to decrease $\left(p_{\text {trend }}=0.065\right)$ similarly to T3/T4 ratio $\left(p_{\text {trend }}=0.063\right)$, and the fT3/fT4 ratio also decreased $\left(\mathrm{p}_{\text {trend }}=0.005\right)$. It seems that the treatment of thyroid disease in patients with renal failure, treated with haemodialysis, is not associated with change of rT3 and conversion factor levels.

Conclusions: The concentration of rT3 in HD patients in relation to healthy persons tends to decrease, and hypothyroidism increases this tendency in these patients. Hormone substitution treatment does not eliminate the influence of RF on inhibition of rT3 production. In patients with ESRD, hypothyroidism additionally reduces the conversion of thyroid hormones examined by fT3/fT4 and to a lesser extent T3/T4 ratios. (Endokrynol Pol 2019; 70 (2): 165-171)
\end{abstract}

Key words: end-stage renal disease; thyroid hormone conversion; hypothyroidism; substitution treatment; rT3

\section{Introduction}

The number of patients with chronic kidney disease (CKD), including patients on renal replacement therapy, is constantly rising. Despite the increasing use of dialysis, mortality and morbidity in these groups of patients is still high and the quality of life is low [1,2].

In CKD patients, disorders in other organs and systems also occur. One of the disorders is hypothyroidism, which, both overt and subclinical, is found more frequently than in the general population. Disorders of thyroid hormone metabolism in patients with CKD are associated with an increase in the concentration of uremic toxins that selectively inhibit the transcriptional activity by blocking triiodothyronine (T3) receptors. At the same time, acidosis and high parathyroid hormone (PTH) concentration in secondary hyperparathyroidism impair the conversion of thyroxine (T4 toT3, and an increase in phosphate ion concentration may lead to disturbance of T4 binding to transport proteins and an decrease in concentration of free thyroxine (fT4) fraction [3-5].

In patients with end-stage renal disease (ESRD) a significant reduction in T3 production is found. However, in contrast to other chronic diseases, no increase in rT3 concentration in RF is observed because impaired T4 toT3 conversion does not increase the activity of the pathway for the production of rT3 $[3,4,6]$. 
The inclusion of substitution treatment and normalisation of thyroid hormone and TSH concentrations in patients with ESRD can have a beneficial effect on kidney function [2, 3].

Despite this knowledge, it is not established whether the conversion of thyroid hormones is significantly different in patients with hypothyroidism and coexisting $\mathrm{RF}$, and how this situation affects rT3 concentrations.

\section{The aim of the study}

The objective of the study was to evaluate the influence of coexisting hypothyroidism and thyroid hormone therapy in patients with ESRD on thyroid hormone conversion ratios and rT3 concentration.

\section{Material and methods}

The study involved 85 patients aged 26 to 87 years, with a mean age of $59.62 \pm 15.45$ years. Forty-six women and 39 men were examined, including: G1 group -25 persons (F16, M9) aged 28-83 years, with mean age of $51.24 \pm 12.58$ without RF and hypothyroidism, G2 - 26 patients (F10, M16) aged 26-82 years with mean age of $58.85 \pm 15.52$ years with ESRD treated with haemodialysis (HD), G3 - 12 patients $(\mathrm{F} 6, \mathrm{M} 6)$ aged 37-83 with mean age of $66.80 \pm$ 12.90 years with ESRD treated with $\mathrm{HD}$ and newly diagnosed hypothyroidism, and G4 - 22 HD patients (F14, M8) aged 31-87 years with mean age of $66.14 \pm 15.54$ with hypothyroidism treated substitutionally with thyroid hormones.

In all patients the following tests were performed: gasometry, total protein, C-reactive protein (CRP), creatinine, urea, $\mathrm{TSH}$, and thyroid hormone concentrations: total thyroxine (T4), total triiodothyronine (T3), free thyroxine (fT4) fraction, free triiodothyronine (fT3) fraction, and rT3. The fT3/fT4, T3/T4, rT3/T4, and rT3/T3 conversion ratios were calculated.

The anion gap (AG) for the studied groups was calculated according to the equation $\left(\mathrm{AG}=\left[\mathrm{Na}^{+}\right]-\left(\left[\mathrm{Cl}^{-}\right]+\left[\mathrm{HCO}_{3}\right]\right)\right.$. Patients with ESRD treated in the HD program were examined on a scheduled dialysis day.

\section{Statistical analysis}

Basic descriptive statistics were used, and verification of hypotheses regarding comparisons between two groups was performed using Student's t-test or the Mann-Whitney nonparametric test depending on the fulfilment of the assumptions regarding the distribution of the examined variables. Verification of hypotheses regarding comparisons between more than two groups was performed using analysis of variance or the Kruskal-Wallis nonparametric test (depending on the distribution). Bonferroni correction for multiple testing was applied. Trend analysis was performed using the linear trend test in the analysis of variance or the Jonckheere-Terpstra test. In the case of categorical variables, the chi-square test or the Fisher test were used, also for the linear trend. The significance level of 0.05 was adopted.

\section{Results}

Eighty-five patients were examined in groups G1 to G4. The groups did not differ in terms of gender $(p=0.189$ and $\mathrm{p}=0.440$ ) although females prevailed in the group with ESRD and treated hypothyroidism (G4 - 63.6\%) and in the group without RF and hypothyroidism (G1
- 64.0\%) but not in the group with ESRD and normal thyroid function (G2 only 38.5\%). The number of females and males in the group with RF and newly diagnosed hypothyroidism (G3) was comparable (50\% each).

Patients from group G1 through G2 to G3 were older $\left(\mathrm{p}_{\text {trend }}=0.002\right)$, with lower Hb level $\left(\mathrm{p}_{\text {trend }}<0.001\right)$, lower $\mathrm{pH}\left(\mathrm{p}_{\text {trend }}<0.001\right)$, increased anion gap $\left(\mathrm{p}_{\text {trend }}<0.013\right)$ and CRP concentrations (ptrend $<0.001$ ), and decreased total protein level ( $\left.p_{\text {trend }}<0.001\right)$ (Tab. I).

As shown in Table II, along with the transition from group G1 through G2 to G3, there were increased TSH values ( $\left.\mathrm{p}_{\text {trend }}<0.001\right)$ and lower fT4 ( $\left.\mathrm{p}_{\text {trend }}<0.001\right)$, $\mathrm{T} 4\left(\mathrm{p}_{\text {trend }}=0.024\right), \mathrm{fT} 3\left(\mathrm{p}_{\text {trend }}<0.001\right)$, and T3 $\left(p_{\text {trend }}<0,001\right)$ levels. $r T 3$ values were also decreased $\left(\mathrm{p}_{\text {trend }}=0,008\right)$, especially in both groups treated with haemodialysis in relation to the group of healthy people $\left(\mathrm{G} 3-\mathrm{p}_{\text {trend }}=0.008\right)(\mathrm{Tab} . \mathrm{II})$.

Further analysis of the examined groups from G1 to G3 shows that: rT3/T3 ratio basically did not change, $\mathrm{rT3} / \mathrm{T} 4$ ratio tended to decrease $\left(\mathrm{p}_{\text {trend }}=0.065\right)$ similarly to $\mathrm{T} 3 / \mathrm{T} 4$ ratio $\left(\mathrm{p}_{\text {trend }}=0.063\right)$, and $\mathrm{fT} 3 / \mathrm{fT} 4$ ratio was also decreased $\left(p_{\text {trend }}=0.005\right)$. Despite the fT3/fT4 trend shown, ESRD patients without hypothyroidism (G2) did not differ from the control group (G1) ( $p=0.558)$. There was a significant difference between the control group (G1) and the group of patients with ESRD and with hypothyroidism (G3) $(\mathrm{p}=0.002)$ and groups with renal failure without hypothyroidism (G2) and with hypothyroidism (G3) ( $\mathrm{p}=0.041)$ (Tab. III).

It seems that the treatment of thyroid disease in patients with ESRD, treated with haemodialysis, is not associated with change of rT3, conversion ratios, and rT3/T3 ratio (Tab. IV).

\section{Discussion}

Subclinical or overt hypothyroidism is diagnosed in many ESRD patients. Hormonal disturbances, as several researchers have noted, intensify with the development of RF [1, 2]. A number of factors influence the above-mentioned disorders, the isolation of which is important for understanding the pathogenesis of hormonal disturbances.

The study assessed the influence of coexisting hypothyroidism as well as substitution treatment on conversion ratios and $\mathrm{rT} 3 / \mathrm{T} 3$ ratio in patients with $\mathrm{RF}$, in whom concentrations of thyroid hormones, both total and free fractions, are frequently decreased $[3,4]$. The reason for the reduction in the concentration of thyroid hormones is abnormalities resulting from disorders of thyroid hormone synthesis, hormone degradation, conversion and transport with the participation of proteins. The regulation of the hypothalamus-pituitary-thyroid axis is also disturbed [7]. 
Table I. Characteristics of studied groups

\begin{tabular}{|c|c|c|c|c|c|c|c|c|}
\hline Group & & Age & $\mathrm{Hb}$ & $\mathrm{pH}$ & $\mathrm{HCO}_{3}$ & Anion gap* & CRP* & Total protein \\
\hline \multirow{6}{*}{$\begin{array}{l}\text { G3 } \\
\text { ESRD, newly diagnosed } \\
\text { hypothyroidism }\end{array}$} & No. & 12 & 12 & 12 & 12 & 9 & 12 & 12 \\
\hline & Mean & 66.83 & 9.84 & 7.28 & 22.29 & 12.78 & 3.31 & 6.10 \\
\hline & SD & 12.90 & 1.84 & 0.07 & 2.78 & 5.70 & 2.62 & 0.88 \\
\hline & Median & 68.00 & 9.70 & 7.26 & 22.60 & 14.00 & 3.25 & 5.85 \\
\hline & Minimum & 37 & 7.5 & 7.2 & 17.1 & 2.0 & 0.3 & 4.8 \\
\hline & Maximum & 83 & 13.5 & 7.4 & 26.6 & 20.0 & 7.6 & 7.5 \\
\hline \multirow{6}{*}{$\begin{array}{l}\text { G2 } \\
\text { ESRD, without } \\
\text { hypothyroidism }\end{array}$} & No. & 26 & 26 & 26 & 26 & 26 & 26 & 26 \\
\hline & Mean & 58.85 & 11.07 & 7.32 & 24.48 & 13.38 & 0.845 & 6.72 \\
\hline & SD & 15.522 & 2.17 & 0.07 & 2.77 & 5.90 & 0.67 & 0.67 \\
\hline & Median & 60.00 & 10.85 & 7.32 & 24.50 & 14.00 & 0.70 & 6.85 \\
\hline & Minimum & 26 & 8.4 & 7.2 & 18.6 & 0.0 & 0.10 & 5.3 \\
\hline & Maximum & 82 & 19.4 & 7.5 & 31.2 & 21.0 & 2.4 & 7.7 \\
\hline \multirow{6}{*}{$\begin{array}{l}\text { G1 } \\
\text { Without RF, without } \\
\text { hypothyroidism }\end{array}$} & No. & 25 & 24 & 25 & 25 & 13 & 21 & 25 \\
\hline & Mean & 51.24 & 13.67 & 7.37 & 27.94 & 7.38 & 0.26 & 7.03 \\
\hline & SD & 12.581 & 1.48 & 0.052 & 2.66 & 3.36 & 0.32 & 0.56 \\
\hline & Median & 51.00 & 14.05 & 7.36 & 27.90 & 7.00 & 0.20 & 7.00 \\
\hline & Minimum & 28 & 11.1 & 7.3 & 23.3 & 3.0 & 0.0 & 5.8 \\
\hline & Maximum & 83 & 16.5 & 7.5 & 34.1 & 16.0 & 1.4 & 8.1 \\
\hline $\mathbf{p}_{\text {trend }}$ & & 0.002 & $<0.001$ & $<0.001$ & $<0.001$ & 0.013 & $<0.001$ & $<0.001$ \\
\hline p & & 0.007 & $<0.001$ & 0.001 & $<0.001$ & 0.028 & $<0.001$ & 0.001 \\
\hline $\mathbf{p}_{\mathrm{G} 1 \text { vs. G2 }}$ & & 0.168 & $<0.001$ & 0.047 & $<0.001$ & 0.006 & 0.001 & 0.318 \\
\hline $\mathbf{P}_{\mathrm{G} 2 \text { vs. G3 }}$ & & 0.317 & 0.196 & 0.161 & 0.075 & 1.000 & 0.099 & 0.028 \\
\hline $\mathbf{p}_{\mathrm{G1} \text { vs. G3 }}$ & & 0.007 & $<0.001$ & 0.001 & $<0.001$ & 0.083 & $<0.001$ & 0.001 \\
\hline
\end{tabular}

${ }^{*} p_{\text {trend }}$ - value from Jonckheere-Terpstra test, in other cases — p-value from analysis of variance test, $p$ from Kruskal-Wallis test, in other cases — $p$-value from analysis of variance test; $\mathrm{p}_{\mathrm{G} 1 \text { vs. G2}{ }^{\prime}} \mathrm{p}_{\mathrm{G} 2 \text { vs' } \mathrm{G}^{\prime}} \mathrm{p}_{\mathrm{G} 1 \text { vs. G3 }}$ for Bonferroni correction for multiple testing; ESRD — end-stage renal disease; RF — renal failure;

$\mathrm{Hb}$ - haemoglobin; $\mathrm{HCO}_{3}$ - bicarbonate; CRP 33 C-reactive protein

Table II. Concentrations of thyroid hormones and TSH in studied groups

\begin{tabular}{|c|c|c|c|c|c|c|c|}
\hline Group & & TSH* & T4 & T3 & fT4 & fT3 & rT3* \\
\hline \multirow{6}{*}{$\begin{array}{l}\text { G3 } \\
\text { ESRD, newly diagnosed } \\
\text { hypothyroidism }\end{array}$} & No. & 12 & 11 & 11 & 12 & 12 & 11 \\
\hline & Mean & 13.56 & 83.67 & 1.14 & 12.02 & 2.35 & 226.75 \\
\hline & SD & 15.50 & 28.24 & 0.30 & 3.07 & 1.11 & 143.07 \\
\hline & Median & 7.74 & 84.82 & 1.11 & 12.08 & 2.03 & 216.39 \\
\hline & Minimum & 4.20 & 35.39 & 0.64 & 6.21 & 1.14 & 24.32 \\
\hline & Maximum & 58.10 & 121.60 & 1.60 & 16.78 & 4.60 & 415.73 \\
\hline \multirow{6}{*}{$\begin{array}{l}\text { G2 } \\
\text { ESRD, without } \\
\text { hypothyroidism }\end{array}$} & No. & 26 & 23 & 23 & 26 & 26 & 23 \\
\hline & Mean & 1.62 & 93.37 & 1.54 & 14.87 & 3.77 & 253.97 \\
\hline & SD & 0.97 & 25.24 & 0.43 & 2.61 & 1.00 & 187.37 \\
\hline & Median & 1.32 & 91.80 & 1.45 & 14.40 & 3.51 & 174.70 \\
\hline & Minimum & 0.42 & 52.47 & 0.93 & 10.80 & 2.44 & 34.10 \\
\hline & Maximum & 4.03 & 167.90 & 2.63 & 20.42 & 7.06 & 719.32 \\
\hline
\end{tabular}


Table II. Concentrations of thyroid hormones and TSH in studied groups

\begin{tabular}{|c|c|c|c|c|c|c|c|}
\hline Group & & TSH* $^{*}$ & T4 & T3 & fT4 & fT3 & rT3* \\
\hline \multirow{6}{*}{$\begin{array}{l}\text { G1 } \\
\text { Without RF, without } \\
\text { hypothyroidism }\end{array}$} & No. & 25 & 25 & 25 & 25 & 25 & 20 \\
\hline & Mean & 1.43 & 102.18 & 1.80 & 16.59 & 4.60 & 378.59 \\
\hline & SD & 0.95 & 16.41 & 0.34 & 2.61 & 0.92 & 157.28 \\
\hline & Median & 1.10 & 100.50 & 1.72 & 15.83 & 4.48 & 372.30 \\
\hline & Minimum & 0.43 & 76.46 & 1.19 & 12.70 & 2.69 & 73.73 \\
\hline & Maximum & 4.07 & 138.00 & 2.43 & 22.27 & 6.36 & 689.23 \\
\hline $\mathbf{p}_{\text {trend }}$ & & $<0.001$ & 0.024 & $<0.001$ & $<0.001$ & $<0.001$ & 0.008 \\
\hline $\mathbf{p}$ & & $<0.001$ & 0.075 & $<0.001$ & $<0.001$ & $<0.001$ & 0.020 \\
\hline $\mathbf{p}_{\mathrm{G1} \mathrm{vs.} \mathrm{G2}}$ & & 1.000 & & 0.054 & 0.080 & 0.001 & 0.048 \\
\hline $\mathbf{p}_{\mathrm{G} 2 \text { vs. G3 }}$ & & $<0.001$ & & 0.016 & 0.011 & $<0.001$ & 1.000 \\
\hline $\mathbf{p}_{\mathrm{G1} \mathrm{vs.} \mathrm{G3}}$ & & $<0.001$ & & $<0.001$ & $<0.001$ & $<0.001$ & 0.058 \\
\hline
\end{tabular}

${ }^{*} \mathrm{p}_{\text {trend }}$-value from Jonckheere-Terpstra test, in other cases — $\mathrm{p}$-value from analysis of variance test; $\mathrm{p}$ from Kruskal-Wallis test, in other cases — $\mathrm{p}$-value from analysis of variance test, $\mathrm{p}_{\mathrm{G} 1 \text { vs. G2, }}, \mathrm{p}_{\mathrm{G} 2 \text { vs G } 3^{\prime}} \mathrm{p}_{\mathrm{G} 1 \text { vs. } 63}$ for Bonferroni correction for multiple testing; ESRD — end-stage renal disease; RF — renal failure; T4 - thyroxine;

$\mathrm{T} 3$ - triiodothyronine; $\mathrm{fT} 4$ - free thyroxine; $\mathrm{fT} 3$ - free triiodothyronine

Table III. Thyroid hormone conversion ratios and rT3/fT3 ratio in studied groups

\begin{tabular}{|c|c|c|c|c|c|}
\hline Group & & rT3/T3* & $\mathrm{rT3} / \mathrm{T} 4 *$ & $\mathrm{~T} 3 / \mathrm{T} 4$ & $\mathrm{fT} 3 / \mathrm{fT} 4$ \\
\hline \multirow{6}{*}{$\begin{array}{l}\text { G3 } \\
\text { ESRD, newly diagnosed hypothyroidism }\end{array}$} & No. & 11 & 11 & 11 & 12 \\
\hline & Mean & 216.81 & 2.87 & 0.015 & 0.196 \\
\hline & SD & 182.23 & 2.39 & 0.004 & 0.070 \\
\hline & Median & 166.45 & 1.78 & 0.013 & 0.189 \\
\hline & Minimum & 29.23 & 0.69 & 0.010 & 0.08 \\
\hline & Maximum & 651.62 & 8.26 & 0.020 & 0.32 \\
\hline \multirow{6}{*}{$\begin{array}{l}\text { G2 } \\
\text { ESRD, without hypothyroidism }\end{array}$} & No. & 23 & 23 & 23 & 26 \\
\hline & Mean & 173.57 & 2.93 & 0.017 & 0.264 \\
\hline & SD & 137.98 & 2.25 & 0.006 & 0.093 \\
\hline & Median & 110.55 & 2.06 & 0.017 & 0.251 \\
\hline & Minimum & 22.58 & 0.43 & 0.01 & 0.13 \\
\hline & Maximum & 609.60 & 8.11 & 0.03 & 0.53 \\
\hline \multirow{6}{*}{$\begin{array}{l}\text { G1 } \\
\text { Without RF, without hypothyroidism }\end{array}$} & No. & 20 & 20 & 25 & 25 \\
\hline & Mean & 205.80 & 3.66 & 0.018 & 0.281 \\
\hline & SD & 91.30 & 1.37 & 0.003 & 0.058 \\
\hline & Median & 198.38 & 3.62 & 0.018 & 0.277 \\
\hline & Minimum & 44.68 & 0.61 & 0.01 & 0.18 \\
\hline & Maximum & 408.75 & 5.50 & 0.03 & 0.42 \\
\hline $\mathbf{p}_{\text {trend }}$ & & 0.338 & 0.065 & 0.063 & 0.005 \\
\hline $\mathbf{P}$ & & 0.260 & 0.130 & 0.140 & 0.003 \\
\hline $\mathbf{p}_{\mathrm{G1} \text { vs. G2 }}$ & & 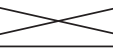 & & & 0.558 \\
\hline $\mathbf{p}_{\mathrm{G} 2 \text { vs. G3 }}$ & & & & & 0.041 \\
\hline $\mathbf{p}_{\mathrm{G1} \text { vs. G3 }}$ & & & & & 0.002 \\
\hline
\end{tabular}


Table IV. Concentrations of TSH, thyroid hormones, thyroid hormone conversion ratios, and rT3/fT3 ratio in treated hypothyroidism in HD patients

G4

G3

ESRD, treated hypothyroidism

ESRD, newly diagnosed hypothyroidism

\begin{tabular}{lccccccccc} 
& $\mathbf{N}$ & Mean \pm SD & Median & Range & $\mathbf{N}$ & Mean \pm SD & Median & Range & \\
\hline TSH* $^{*}$ & 19 & $2.9 \pm 2.45$ & 1.56 & $0.14-8.56$ & 12 & $13.56 \pm 15.5$ & 7.74 & $4.2-58.1$ & $<0.001$ \\
\hline T4 & 20 & $90.54 \pm 22.41$ & 90.15 & $44.52-134.7$ & 11 & $83.67 \pm 28.24$ & 84.82 & $35.39-121.6$ & 0.462 \\
\hline T3 & 20 & $1.23 \pm 0.3$ & 1.22 & $0.59-1.94$ & 11 & $1.14 \pm 0.3$ & 1.11 & $0.64-1.6$ & 0.412 \\
\hline $\mathbf{f T 4}$ & 20 & $16.03 \pm 3.98$ & 15.37 & $9.95-26.18$ & 12 & $12.02 \pm 3.07$ & 12.08 & $6.21-16.78$ & 0.005 \\
\hline fT3 & 20 & $3.21 \pm 1.37$ & 2.93 & $1.54-8.24$ & 12 & $2.35 \pm 1.11$ & 2.03 & $1.14-4.6$ & 0.076 \\
\hline rT3* & 20 & $198.72 \pm 91.84$ & 185.36 & $61.79-367.87$ & 11 & $226.75 \pm 143.07$ & 216.39 & $24.32-415.73$ & 0.650 \\
\hline rT3/T3* & 20 & $169.60 \pm 87.76$ & 170.77 & $51.92-357.16$ & 11 & $216.81 \pm 182.23$ & 166.45 & $29.23-651.62$ & 0.710 \\
\hline rT3/T4* & 20 & $2.32 \pm 1.23$ & 2.16 & $0.92-4.79$ & 11 & $2.87 \pm 2.39$ & 1.78 & $0.69-8.26$ & 0.773 \\
\hline T3/T4 & 20 & $0.014 \pm 0.004$ & 0.013 & $0.01-.03$ & 11 & $0.015 \pm 0.004$ & 0.013 & $0.01-0.02$ & 0.857 \\
\hline fT3/fT4 & 20 & $0.208 \pm 0.086$ & 0.182 & $0.11-.42$ & 12 & $0.196 \pm 0.070$ & 0.189 & $0.08-0.32$ & 0.703 \\
\hline
\end{tabular}

${ }^{*} \mathrm{p}$-value from Mann-Whitney test, in other cases — p-value from t-Student test; ESRD — end-stage renal disease; TSH — thyroid stimulating hormone;

T4 — thyroxine; T3 — triiodothyronine; fT4 — free thyroxine; fT3 — free triiodothyronine; SD — standard deviation

T4 and fT4 concentrations in RF may be normal or slightly reduced, but dialysis patients may show increased fT4 and decreased T4 concentration, which is probably associated with T4-protein binding disorders caused by heparin administered during $\operatorname{HD}[5,8$, 9]. In the presented study, decreased values of T4, fT4, T3, and fT3 were also found in HD patients with the lowest concentration of fT4, T3, and fT3 in HD patients with newly diagnosed hypothyroidism, which may result from worse general condition of patients (Tab. II). Similar, but less significant, tendencies were found for total T4 concentrations $\left(\mathrm{p}_{\text {trend }}=0.024\right)$. The group of HD patients with newly diagnosed hypothyroidism had the worst laboratory results (lowest $\mathrm{Hb}$, highest CRP, lowest total protein, lowest $\mathrm{pH}$ and bicarbonate), which can also disturb thyroid hormone metabolism (Tab. I). Similar relationships for thyroid hormones were observed by other researchers who associated decreased T4 concentrations with acidosis, reduced albumin concentration and anaemia $[3,7,8,10]$. Additionally, the literature showed a negative correlation of total T4 concentration with urea [9].

The low concentration of total T3 in CKD patients appears to be one of the most important causes of mortality in euthyroid patients and may affect up to $39 \%$ of CKD patients $[1,2,11,12]$. Our study showed statistically significant lower T3 and fT3 concentrations in all examined groups of HD patients as compared to control group (Tab. II). Our results are confirmed by other investigators [11-14]. The reduction of T3 concentration results from a reduction of 5'-deiodinase (D1) activity and an increase in 5-deiodinase (D3) activity, but not from a decrease in T4 availability [11-14]. In the population of patients with ESRD, low concentration of total T3 may also have been due to removing the free hormone through $\mathrm{HD}$, reduced number of $\mathrm{T} 3$ bindings, increased catabolism of the hormone, decreased T3 secretion by the thyroid gland, and finally, reduced T4 to T3 non-thyroidal conversion [12-15].

In the presented study, in the groups of ESRD patients treated with haemodialysis, we found elevated CRP concentration ( $\geq 0.8 \mathrm{mg} / \mathrm{dl}$ ) especially in patients with newly diagnosed hypothyroidism (Tab. I). The association of elevated concentrations of CRP and proinflammatory cytokines as well as decreased albumin and $\mathrm{Hb}$ concentrations with total $\mathrm{T} 3$ has also been shown by other researchers $[3,16,17]$.

Despite worse prognosis in patients with ESRD, the indications for treatment of low T3 syndrome remain uncertain. While administration of levothyroxine effectively increased total T4 concentration to a level sometimes higher than normal, total T3 concentration remained higher but still low (Tab. IV). These data, combined with a low $\mathrm{T} 3 / \mathrm{T} 4$ ratio, suggest that low concentration of total T3 in uremic patients may be due to abnormal peripheral thyroid hormone conversion (Tab. III). Similar suggestions can be found in other papers $[3,18]$.

Elevated rT3 concentration is characteristic of severe chronic diseases and is associated with worse prognosis and shorter survival, especially in older people $[4,19$, 20]. This situation is probably explained by decreased D1 activity, decreased rT3 uptake by the liver and the increased D3 activity $[14,15,21]$. In patients with RF the lack of elevation in total rT3 concentration is observed because in these patients the lower T4 to T3 conversion 
does not intensify the activity of the pathway for the production of rT3. The decrease in rT3 concentration is also explained by its redistribution from vessels to extravascular space and the increase of rT3 cellular uptake [23]. In the present study, lower rT3 values were observed in dialysis patients than in patients without RF. Hypothyroidism did not increase rT3 concentration, although in patients without RF and without hypothyroidism the rT3 concentration was elevated, which is consistent with the results of other researchers (Tab. II) $[11,14,22]$.

Replacement therapy with thyroid hormones did not increase rT3 concentrations in HD patients, which suggests that the pathway for the production of rT3 is blocked by the condition of renal failure; this seems to be an important statement of the presented work (Tab. IV). Positive correlation between concentrations of rT3 and total protein was found in patients without ESRD, but this might be associated with the nutrition status of the patients $[6,23]$. Treatment with thyroid hormones in this group of patients did not change the conversion rates (Tab. IV). The metabolic significance of these disorders remains unclear and requires further research due to lack of accurate literature data.

Disorders of thyroid hormone metabolism in people with ESRD are a very common phenomenon, and the most frequent are disturbances in the thyroid hormone T4 to T3 conversion. The principal factor impacting the conversion of thyroid hormones is the activity of deiodinases. In order to determine the conversion ratio of thyroid hormones, conversion ratios (T3/T4, $\mathrm{fT3} / \mathrm{fT} 4, \mathrm{rT3} / \mathrm{T} 4)$ and the rT3/T3 ratio are used, allowing an estimation of the intensity of thyroid hormone metabolism $[12,26]$.

In the presented study, the values of fT3/fT4 conversion ratio tend to be statistically significantly lower in the group of patients with RF, and the values of the T3/T4 ratio are on the borderline of statistical significance (Tab. III), which was also noted in the works of other researchers $[11,24]$. They believe that in patients with CKD the value of the T3/T4 conversion ratio is reduced proportionally to the activity of D1 deiodinase $[6,11,25]$. In people with thyroid dysfunction, the T3/T4 conversion ratio also changes - in hypothyroidism its value decreases, and in hyperthyroidism it increases, which is also described in the literature [26].

Our study showed a tendency towards reduction of the rT3/T4 conversion ratios (on the borderline of statistical significance) in ESRD patients treated with HD (Tab. III), which is related to the activity of D3 in the liver [11]. In patients treated with dialysis, D1 activity is reduced and D3 activity is elevated [11,24]. The rT3/T3 ratio was considered a very good marker reflecting disturbances of peripheral thyroid hormone metabolism in severe diseases, but we did not find any significant changes of this factor in our work (Tab. III) [11]. Data in the literature prove that the increase in the value of rT3/T3 ratio is associated with worse prognosis and shorter survival, especially in older people $[11,18,24]$.

\section{Conclusions}

The concentration of rT3 in ESRD patients treated with $\mathrm{HD}$ in relation to healthy persons tends to decrease, and hypothyroidism increases this tendency in these patients. Hormonal substitution treatment does not eliminate the influence of RF on inhibition of rT3 production. In patients with ESRD, hypothyroidism additionally reduces the conversion of thyroid hormones examined by fT3/fT4 and to a lesser extent T3/T4 ratios.

\section{Information on grants}

The study was performed with Bioethical Commission approval and was financed by project No. 42 - grant of the Young Scientist of the Military Institute of Medicine in Warsaw.

\section{References}

1. Singh S, Verma A, Aryal G, et al. Prevalence of thyroid hormone abnormalities in stage 5 chronic kidney disease: a tertiary care center study of Nepal. Int J Res Med Sci. 2016: 3929-3933, doi: 10.18203/2320-6012. ijrms20162910.

2. Dash HS. Thyroid Dysfunction in chronic kidney disease. Indian J Appl Res. 2016; 6: 348-349.

3. Carrero JJ, Qureshi AR, Axelsson J, et al. Clinical and biochemical implications of low thyroid hormone levels (total and free forms) in euthyroid patients with chronic kidney disease. J Intern Med. 2007; 262(6): 690-701, doi: 10.1111/j.1365-2796.2007.01865.x, indexed in Pubmed: 17908160.

4. Enia G, Panuccio V, Cutrupi S, et al. Subclinical hypothyroidism is linked to micro-inflammation and predicts death in continuous ambulatory peritoneal dialysis. Nephrol Dial Transplant. 2007; 22(2): 538-544, doi: 10.1093/ndt/gfl605, indexed in Pubmed: 17082213.

5. Csako G, Zweig MH, Glickman J, et al. Direct and indirect techniques for free thyroxin compared in patients with nonthyroidal illness. I. Effect of free fatty acids. Clin Chem. 1989; 35(1): 102-109, indexed in Pubmed: 2491973.

6. Padhy S, Devi A. Evalution of thyroid hormone status in chronic renal failure. Int J Pharm Bio. 2014; 5: 171-175.

7. Wiederkehr MR, Kalogiros J, Krapf R. Correction of metabolic acidosis improves thyroid and growth hormone axes in haemodialysis patients. Nephrol Dial Transplant. 2004; 19(5): 1190-1197, doi: 10.1093/ndt/gfh096, indexed in Pubmed: 14993483.

8. Majeed HM, Mazin MR. Association between chronic renal failure and thyroid hormone. Indian JAppl Res. 2016; 6: 348-349.

9. Liewendahl K, Tikanoja S, Mähönen H, et al. Concentrations of iodothyronines in serum of patients with chronic renal failure and other nonthyroidal illnesses: role of free fatty acids. Clin Chem. 1987; 33(8): 1382-1386, indexed in Pubmed: 3111749.

10. Baur A, Bauer K, Jarry H, et al. Effects of proinflammatory cytokines on anterior pituitary $5^{\prime}$-deiodinase type I and type II. J Endocrinol. 2000; 167(3): 505-515, indexed in Pubmed: 11115778.

11. Peeters RP, Wouters PJ, van Toor H, et al. Serum $3,3^{\prime}, 5^{\prime}$-triiodothyronine (rT3) and 3,5,3'-triiodothyronine/rT3 are prognostic markers in critically ill patients and are associated with postmortem tissue deiodinase activities. J Clin Endocrinol Metab. 2005; 90(8): 4559-4565, doi: 10.1210/jc.2005-0535, indexed in Pubmed: 15886232.

12. Niemczyk S, Sokalski A, Matuszkiewicz-Rowińska J, et al. Konwersja hormonalna T4 do T3 u chorych ze schyłkowa niewydolnością nerek (SNN). Nefrol Dial Pol. 2009; 13: 148-152. 
13. Peeters RP, Wouters PJ, Kaptein E, et al. Reduced activation and increased inactivation of thyroid hormone in tissues of critically ill patients. J Clin Endocrinol Metab. 2003; 88(7): 3202-3211, doi: 10.1210/jc.2002-022013, indexed in Pubmed: 12843166.

14. den Brinker M, Joosten KFM, Visser TJ, et al. Euthyroid sick syndrome in meningococcal sepsis: the impact of peripheral thyroid hormone metabolism and binding proteins. J Clin Endocrinol Metab. 2005; 90(10): 5613-5620, doi: 10.1210/jc.2005-0888, indexed in Pubmed: 16076941.

15. Zoccali C, Tripepi G, Cutrupi S, et al. Low triiodothyronine: a new facet of inflammation in end-stage renal disease. J Am Soc Nephrol. 2005; 16(9): 2789-2795, doi: 10.1681/ASN.2005040356, indexed in Pubmed: 16033857.

16. Rodrigues MCS, Santos GM, da Silva CA, et al. Thyroid hormone transport is disturbed in erythrocytes from patients with chronic renal failure on hemodialysis. Ren Fail. 2004; 26(4): 461-466, indexed in Pubmed: 15462116.

17. Singh AK, Raed A, Kari J. Endocrine complications of chronic kidney disease. In: Kimmel P, Rosenberg M. ed. Chronic Renal Disesae. Elsevier Academic Press, Cambridge 2015.

18. Mohamedali M, Reddy Maddika S, Vyas A, et al. Thyroid disorders and chronic kidney disease. Int J Nephrol. 2014; 2014: 520281, doi: 10.1155/2014/520281, indexed in Pubmed: 24829799.

19. Biondi B, Cooper DS. The clinical significance of subclinical thyroid dysfunction. Endocr Rev. 2008; 29(1): 76-131, doi: 10.1210/er.2006-0043, indexed in Pubmed: 17991805.
20. Horáček J, Dusilová Sulková S, Kubišová M, et al. Thyroid hormone abnormalities in hemodialyzed patients: low triiodothyronine as well as high reverse triiodothyronine are associated with increased mortality. Physiol Res. 2012; 61(5): 495-501, indexed in Pubmed: 22881233.

21. van den Beld AW, Visser TJ, Feelders RA, et al. Thyroid hormone concentrations, disease, physical function, and mortality in elderly men. J Clin Endocrinol Metab. 2005; 90(12): 6403-6409, doi: 10.1210/jc.2005-0872, indexed in Pubmed: 16174720.

22. Dubczak I, Niemczyk L. Fizjologia hormonów tarczycy i przyczyny zaburzeń tarczycowych w przewlekłej niewydolności nerek. Nefrol Dial Pol. 2016; 20: 258-261.

23. Forestier E, Vinzio S, Sapin R, et al. Increased reverse triiodothyronine is associated with shorter survival in independently-living elderly: the Alsanut study. Eur J Endocrinol. 2009; 160(2): 207-214 doi: 10.1530/eje-08-0519, indexed in Pubmed: 19001060.

24. Niemczyk S, Matuszkiewicz-Rowińska J, Sokalski A, et al. Test czynnościowy TRH - TSH u chorych ze schyłkową niewydolnością nerek (SNN). Nefrol Dial Pol. 2008; 12: 176-180.

25. Peeters RP, van der Geyten S, Wouters PJ, et al. Tissue thyroid hormone levels in critical illness. J Clin Endocrinol Metab. 2005; 90(12): 6498-6507, doi: 10.1210/jc.2005-1013, indexed in Pubmed: 16174716.

26. Niemczyk S. Zaburzenia czynności tarczycy oraz hiperprolaktynemia u chorych ze schyłkową niewydolnością nerek. Akademia Medyczna w Warszawie, Warszawa 2004 